The 1st International Conference on Classification, Phylogeny and Natural History of Scolytidae (Coleoptera) July 3-9, 1988 , Vancouver, British Columbia, Canada.

This symposium, held in conjunction with the XVIII International Congress of Entomology, will focus on current research relating to the morphology, systematics, phylogeny, zoogeography, ecology, physiology and behavior of the Scolytidae. Potential participants and topics are now being solicited. Anyone interested in participating in the symposium is asked to notify one of the co-convenors listed below.

\section{D.E. Bright}

Biosystematics Research Centre

Canada Agriculture

K.W. Neatby Building

Ottawa, Ontario, Canada

K1A 0C6

\section{G.N. Lanier \\ Department of Entomology \\ College of Environmental Science and Forestry \\ Syracuse, New York 13210 \\ U.S.A.}

\section{4th World Wilderness Congress}

The 4th WWC will meet in Denver. Colorado, from September 4-11, 1987 Agenda topics will include biological diversity, the role of multinational corporations, endangered species, wildlife and wildlife research and management, financing sustainable development in developing nations, progress of national conservation strategies, and many other subjects. A distinguished list of international scientists will attend and participate in symposia. Pre-and post-congress tours will be available. Registration forms and information may be obtained from the Secretariat, 4 World Wilderness Congress, Colorado State University, Fort Collins, CO USA 80523. Tel. (303) 4915804.
IUFRO Conference on Forest Growth Modelling and Prediction.

An international conference on Forest Growth Modelling and Prediction is scheduled for August 24-28, 1987 in Minneapolis, Minnesota. The meeting is sponsored by the International Union of Forestry Research Organizations Subject Group S4.01 Mensuration, Growth and Yield.

Over 100 papers will be presented on the development of all types of tree and stand growth modelling methodology including: model specification and parameter estimation; evaluation of models; incorporation of silvicultural treatments, site characterization, weather and other environmental perturbations; regeneration models; design of growth studies; and application of growth models in research and management including optimization methodologies. These papers cover all types of forests including tropical, temperate, and boreal regions. Posters, including software descriptions, will also be presented.

The conference is intended for scientists and practitioners developing tree and forest growth models and predictions.

For further information, contact: Alan R. Ek, Program Chairman, College of Forestry, University of Minnesota, St. Paul, MN 55108, USA.

\section{IUFRO Congress to Meet in Montreal in 1990}

Jean-Claude Mercier, Associate Deputy Minister, Canadian Forestry Service has announced that the International Council of the International Union of Forest Research Organizations has awarded the 19th Congress of the Union to Canada. It will be held at the Palais des Congrès in Montreal with the proposed dates August $6-11,1990$. The CFS will act as principal sponsor, but hopes that agencies from all parts of the forest sector will become involved. More than 2000 participants are expected. lufro Working Party S1.05-12

Northern Forest Silviculture and Management 1987 Symposium

The 9th Annual Symposium will be held in northern Finland, August 16-22, 1987. The program consists of five full days of field stops, papers, and a poster session and addresses three subjects:

1) Site preparation in northern boreal forests

2) Forest management close to (northern) timber line

3) Larix in northern boreal forests

Invited papers are expected from North America, Europe, and Asia. English is the spoken language for the Symposium. The Rovaniemi Research Station of the Finnish Forest Research Institute is the host. Space is limited.

For additional information contact:

North America/Asia

Dr. Edmond C. Packee

Agricultural \& Forestry

Experiment Station

University of Alaska

Fairbanks, AK 99775-0080 USA

Telephone: 907-474-5070

Europe/Asia

Dr. Hannu Saarenmaa, Manager

Rovaniemi Research Station

The Finnish Forest Research Institute

Eteleranta 55

SF-96300 Rovaniemi

FINLAND

$(358+60) 15721$

\section{International Polyphenols Group}

The International Polyphenols Group is holding its next biennial conference in the Niagara Falls area of Canada on August $16-19,1988$. Topics of the symposium will be: Biodegradation and utilization of lignin; Significance of flavonoids in foods; Cereal polyphenols; Phenolics in phytopathology and Production of phenolics in cultured tissues. Contributed papers and posters on these and other polyphenol related topics are invited. For further information contact: Dr. T. Fuleki, HRIO, Vineland Station, Ontario, Canada LOR 2EO. 